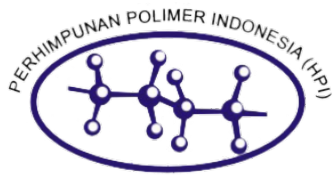

\title{
Effect of Solvents in the Performance of Cellulose Acetate/ Poly(1,4-butylene succinate) Membrane Prepared by Using Phase Inversion Method
}

\author{
Siti Nurkhamidah ${ }^{\mathrm{a}}$, Retno Dwi Nyamiati ${ }^{\mathrm{a}}$, Arnesya Ramadhani ${ }^{\mathrm{a}}$, Bertiningrum Cintya Devi ${ }^{\mathrm{a}}$, Bagus
} Arief Febriansyaha, Yeni Rahmawatia , Ali Altway ${ }^{\mathrm{a}}$

\begin{abstract}
Most of the cellulose acetate (CA) membrane for desalination process was prepared by using the phase inversion method. In this study, CA was modified by poly(1,4-butylene succinate) (PBS) with the addition of PBS was $0-40$ wt $\%$ of the total material used ( $C A$ and $\mathrm{PBS}$ ). CA/PBS membranes have been prepared by using the phase inversion method with the variation of solvents used. The membrane of CA/PBS was prepared by using dimethylformamide (DMF), N-methyl-2pyrrolidone (NMP), and tetrahydrofuran (THF), respectively of which each of the solvents was mixed with acetone in the ratio of 50:50. The hydrophilicity of membranes was characterized by using Fourier Transform Infra-Red (FTIR) and water content. Scanning Electron Microscope (SEM) was used to observe the morphology of the membranes. Salt rejection and permeate flux was analyzed to observe membrane performance. The experiment results show no tendency was shown from the results either in its hydrophilicity or permeate flux. The morphology of membranes shows finger-like and spongelike structures. For all variables of solvents used, salt rejection of membranes increased with the addition of PBS, of which the highest order was obtained from acetone, acetone/NMP, acetone/DMF, and acetone/THF. The best performance of membrane was prepared in acetone CA/PBS 90/10 with the salt rejection of $75 \%$ and permeate flux of $1956.52 \mathrm{~L} / \mathrm{m}^{2} \mathrm{~h}$.
\end{abstract}

Sebagian besar membran selulosa asetat (CA) untuk proses desalinasi dibuat dengan menggunakan metode inversi fasa.
Dalam penelitian ini, CA dimodifikasi oleh poli(1,4-butilena suksinat) (PBS) dengan penambahan PBS 0-40\% berat dari
total bahan yang digunakan (CA dan PBS). Membran CA/PBS dipreparasi menggunakan metode inversi fasa dengan variasi
pelarut yang digunakan. Membran CA/PBS dibuat dengan menggunakan dimethylformamide (DMF), N-methyl-2-
pyrrolidone (NMP), dan tetrahydrofuran (THF), dimana masing-masing pelarut dicampur dengan aseton dengan
perbandingan 50:50. Hidrofilisitas membran dikarakterisasi dengan menggunakan Fourier Transform Infra-Red (FTIR) dan
uji kadar air. Scanning Electron Microscope (SEM) digunakan untuk mengamati morfologi membran. Salt rejection dan
permeate flux dianalisis untuk mengamati kinerja membran. Hasil percobaan tidak menunjukkan kecenderungan baik
dalam hidrofilisitas maupun permeate flux. Morfologi membran menunjukkan struktur seperti jari dan seperti spons.
Untuk semua variabel pelarut yang digunakan, salt rejection terhadap membran meningkat dengan penambahan PBS,
dimana urutan tertinggi diperoleh dari aseton, aseton/NMP, aseton/DMF, dan aseton/THF. Kinerja membran terbaik
didapat dengan preparasi dalam aseton CA/PBS 90/10 dengan salt rejection $75 \%$ dan permeate flux $1956,52 \mathrm{~L} / \mathrm{m}^{2} \mathrm{~h}$.

Received

1 October 2019

Received in revised form

26 December 2019

Accepted

28 December 2019

Published

31 December 2019

Keywords: Cellulose acetate, desalination, membrane, PBS, phase inversion.

\section{Introduction}

Membrane technology is now considered a promising separation tool in various industrial processes such as food, pharmaceutical, biotechnology, pure water production, and wastewater treatment. ${ }^{1}$ Membrane separation processes are preferential compared to the other conventional separation processes for several reasons, such as easy scale-up, lower energy consumption, selective separation of materials, and low space need. ${ }^{2}$

Phase inversion is a suitable method for preparation of polymeric membranes having all types of morphological structures. In a. Chemical Engineering Department, Faculty of Industrial Technology, Institut
Teknologi Sepuluh Nopember (ITS), Kampus ITS Sukolilo Surabaya 6011 Indonesia.

† Corresponding author: nurkhamidah@chem-eng.its.ac.id. this technique, a casting solution comprising of polymer and solvent is immersed into a non-solvent coagulation bath, and a polymer solution is a phase-separated into polymer-rich and polymer lean phases in a controlled manner. ${ }^{3}$ The solidification process is very frequently started by the change from one liquid phase into two liquid phases (liquid-liquid de-mixing). At a certain period during de-mixing, the polymer-rich phase solidifies so that a solid membrane matrix is formed. ${ }^{3,4}$ Membrane morphology, such as pore size can be controlled by choosing different solvents, non-solvents, polymers, pore parameters, and fabrication parameters depending on the specific application. ${ }^{5}$

The first generation cellulose acetate (CA) membranes yield low flux and are susceptible to chemical and bacteriological agents. ${ }^{6} \mathrm{CA}$ performance can be improved by mixing it with appropriate additives to meet new requirements and related membrane properties. Cellulose acetate membranes with different polyvinylpyrrolidone 
(PVP) concentration and coagulation-bath-temperature were prepared by Saljoughi. ${ }^{7}$ They have found that the addition of PVP 0 to $3 \mathrm{wt} . \%$ to the polymer solution increased the macro-voids, and consequently, the pure water flux was raised. However, due to the further addition of PVP to $6 \mathrm{wt}$.\%, the macro-void formation was suppressed, and pure water flux (PWF) was reduced. Cellulose acetate membranes with different polyethylene glycol (PEG) concentration and thermal study were prepared by a group of researchers by Arthanareeswaran, and Kim et al. 6,8 have also investigated the effect of PEG as a pore-former on polysulfone/(NMP) membrane formation using phase inversion process, the have also observed that the membrane surface pore size becomes larger, and the top layer appears more porous, and the distance from the top surface to the starting point of macro-void development becomes greater. On the other hand, they have reported that with increasing of the PEG additive $\mathrm{Mw}$, water flux was increased, and PEG solute (PEG of 12,000 and 35,000 Da used as solutes) rejections were observed to decrease. In general. Cellulose acetate membranes with different poly(butylene succinate) (PBS) concentration were prepared by Ghaffarian. ${ }^{9}$ They have found the best membrane for wastewater purification in variations of CA/PBS (15/85), which has more hydrophilic membrane properties and has the best performance that is turbidity rejection up to $99 \%$. Polymer additives are very important for improving membrane properties, ${ }^{9,10}$ especially pore structure, mechanical stability, thermal stability, hydrophilicity, flux, and rejection ability. ${ }^{5,7}$

The most important family of developed biodegradable polymers includes aliphatic polyesters such as poly (e-caprolactone) (PCL), poly(hydroxy alkanoates) (PHAs), poly(butylene succinate) (PBS), poly(L-lactic acid) (PLA) and poly (butylene adipate) (PBA). ${ }^{11}$ Additionally, PBS, whose ester bonds can be chemically degraded by water, has remarkable processability. ${ }^{12}$

In this study, CA has been modified with PBS with the addition of PBS from 0-40 wt\%. CA/PBS membranes have been prepared by using the phase inversion method with the variation of solvents used. Acetone and mixing solvents of acetone/dimethylformamide (DMF) with ratio 50:50, acetone/N-Methyl-2-pyrrolidone (NMP) with ratio 50:50, and acetone/tetrahydrofuran (THF) also with ratio 50:50 in order to prepare a novel asymmetric membrane with enhanced properties and at the same time extend its practical application as a biodegradable product. The final membrane's characteristics were evaluated in terms of the hydrophilicity, morphology, and performance of the membrane.

\section{Experimental Methods}

\section{Materials}

Cellulose acetate (CA, $\overline{\boldsymbol{M}}_{\boldsymbol{n}}=30,000 \mathrm{Da}$, density $=1.3 \mathrm{~g} \mathrm{~mL}^{-1}$ ); poly(1,4-butylene succinate) (PBS, density $=1.3 \mathrm{~g} \mathrm{~mL}^{-1}$ at $25^{\circ} \mathrm{C}$ ) were purchased from Sigma Aldrich. The solvent used was acetone, 1-methyl-2-pyrrolidone (NMP), dimethylformamide (DMF), tetrahydrofuran (THF), which was supplied from Merck and sodium chloride from Sigma Aldrich.

\section{Method}

\section{Membrane Preparation}

CA/PBS membranes were prepared by phase inversion process as a well-known technique for preparing a variety of membranes. The blend solutions based on CA and PBS were dissolved at different compositions in acetone and a mixture of acetone-NMP, acetoneDMF, and acetone-THF in the ratio of 50:50. The homogeneous solution was cast on a glass plate by a film applicator and moved toward a water bath to complete the phase separation, where the exchange between solvent and the non-solvent (water) was induced. The total solvent was $17 \mathrm{~mL}$ and total polymer was $2.5 \mathrm{~g}$.

Table 1. Compositions of CA/PBS for prepared membranes

\begin{tabular}{cc}
\hline Membrane's code & CA/PBS Blend Ratio \\
\hline 1 & $100: 0$ \\
2 & $90: 10$ \\
3 & $80: 20$ \\
4 & $70: 30$ \\
5 & $60: 40$ \\
6 & $50: 50$ \\
7 & $40: 60$ \\
8 & $30: 70$ \\
\hline
\end{tabular}

CPBA is a variation with acetone solvent, CPBAN variation with acetone-NMP solvent, and CPBAD is a variation with acetone-DMF solvent, and polymer variations are shown in Table 1.

\section{Membrane Characterization Morphology of Membranes}

Cross-sectional and surface morphologies of the membranes were observed by using scanning electron microscopy (SEM). The membranes were frozen in liquid nitrogen, broken, and sputtered with gold before SEM analysis.

\section{Hydrophilicity of Membranes}

Fourier Transform Infrared (FTIR) spectra were performed at the wavenumber of $500-4000 \mathrm{~cm}^{-1}$. Water content is considered to be important characterization parameters as it indirectly indicates the degree of hydrophilicity or hydrophobicity of a membrane. The membrane was kept until constant in the oven with temperature $1000{ }^{\circ} \mathrm{C}$ and prepared for wet sample weight is kept in distilled water and set at room temperature until constant. Water content was calculated using the following equations, where $W C$ stands for water content, $W_{s}$ for wet sample weight, and $D_{s}$ for dried sample weight. ${ }^{13}$

$W C(\%)=\frac{W_{s}-D_{s}}{W_{s}} \times 100 \%$

\section{Membrane Performance}

Water flux and salt rejection were characterized using a crossflow system. This experimental set-up consists of a reservoir, a pump, valves, pressure gauges, and a flat sheet membrane module. Membrane flux was calculated using the following equations:

$F \operatorname{lux}=\frac{Q}{A} \Delta t$

Where $Q$ is the quantity of permeate (L), A is the effective membrane area $\left(\mathrm{m}^{2}\right)$, and $\Delta \mathrm{t}$ is the sampling time $(\mathrm{h}) .{ }^{14}$ Salt rejection was calculated using the following equations. ${ }^{15}$

$\boldsymbol{R}(\%)=\frac{\left(C_{f}-C_{p}\right)}{C_{f}} \times \mathbf{1 0 0} \%$ 
Where $R$ is the salt rejection, and $C_{f}$ and $C_{p}$ are the concentration of the feed and permeate.

\section{Result and Discussion}

Characterization and Performance Membrane CA/PBS with Acetone Solvent

The results of the FTIR analysis show the spectrum of the groups contained in the CA/PBS/Acetone membrane. The hydrophilicity character of a membrane can be analyzed from wavenumber at $1600-1800 \mathrm{~cm}^{-1}$ as the $-\mathrm{OH}$ group in FTIR in Figure 1.

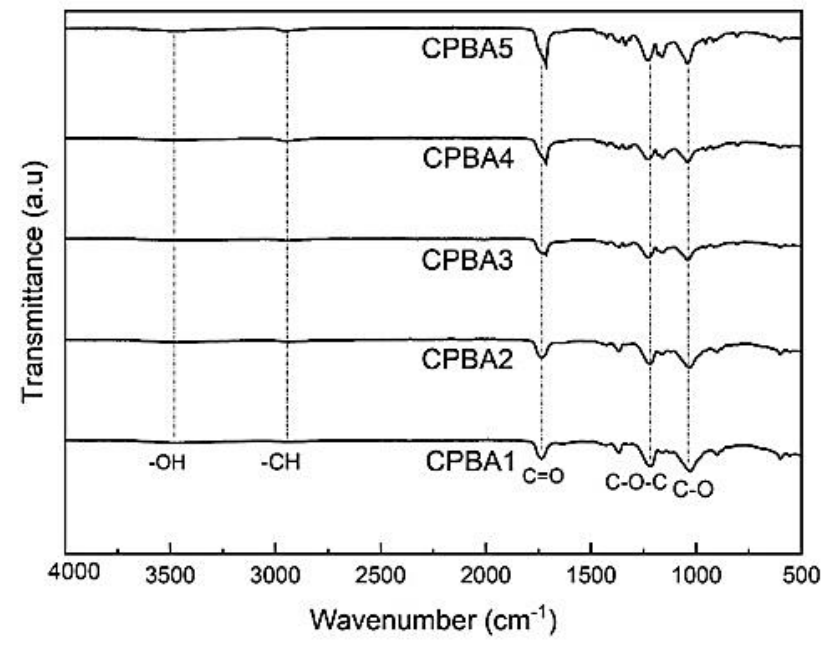

Figure 1. The results of the FTIR analysis.

Peak area of $-\mathrm{OH}$ and pore size of CA/PBS membranes have been calculated from FTIR spectra and SEM images, respectively, and summarized in Table 2. The $-\mathrm{OH}$ area of CA/PBS membrane increases with the addition of PBS up to $10.0 \mathrm{wt} \%$ and decreases with further increasing of PBS contents. This indicates that hydrophilicity of the CA membrane increases with the addition of $10.0 \mathrm{wt} \%$ of PBS. However, hydrophilicity decreases when PBS is more than 10.0 wt\%.

Table 2. Peak $-\mathrm{OH}$ and Pore Size CA/PBS membrane in acetone as a solvent

\begin{tabular}{ccc}
\hline Membrane & $\begin{array}{c}\text { Area of }-\mathrm{OH} \text { peak } \\
\text { (unit area) }\end{array}$ & $\begin{array}{c}\text { Pore Size } \\
(\mu \mathrm{m})\end{array}$ \\
\hline CPBA1 & 4.40 & 0.52 \\
CPBA2 & 4.80 & 0.26 \\
CPBA3 & 4.50 & 1.33 \\
CPBA4 & 4.24 & 1.52 \\
CPBA5 & 3.37 & 2.03 \\
\hline
\end{tabular}

The pore size of the membrane can be calculated from the SEM images, as summarized in Table 2. It can be seen that CPBA2 has the smallest pore size. SEM images show that the CA/PBS membrane exhibits an asymmetric structure. Pure CA in variable CPBA1 has fully porous in the top layer. However, the addition of PBS has gradually changed the final structure of the blend samples to spongy form, whereas their asymmetry has been retained. This result is in agreement with the previous study by Ghaffarian et al. Pore size can also affect the performance result of salt rejection. The smallest of pore size membrane resulting in the smallest amount of salt particles that escapes and causes the rejection increases.

Figure 2 shows the performance of the membrane with the addition of PBS up to $40 \%$. The addition of a $10.0 \mathrm{wt} \%$ PBS increase of salt rejection to $75 \%$ and also exhibits the highest permeate flux. This result is in agreement with FTIR and pore size of membranes. The highest hydrophilicity is CPBA2, which is correlated with permeate flux since the pore size of CPBA2 is small.

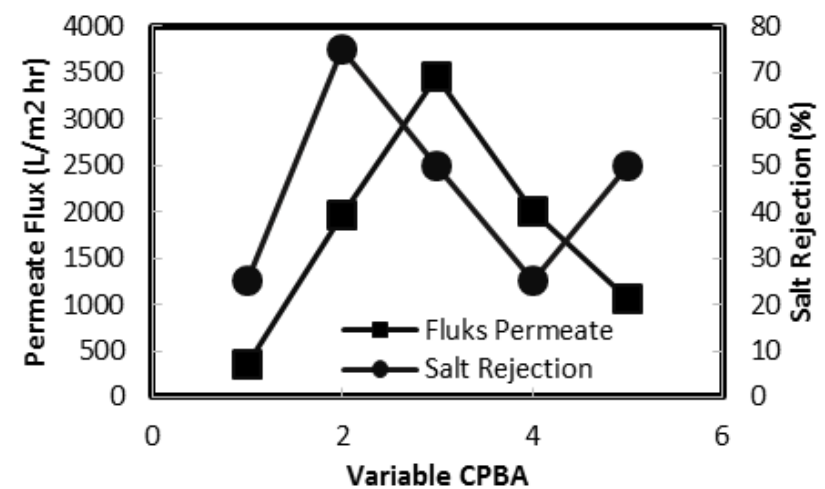

Figure 2. Salt rejection and permeate flux of CA/PBS in acetone Membranes.

The hydrophilicity of membranes is enhanced by the addition of PBS up to $10 \%$. Therefore, improvement of permeate flux by the addition of PBS up to this limit is expectable. However, PBS is more hydrophobic if compared with CA. Consequently, has lower affinity to water as non-solvent in the preparation process. Thus, in PBSrich solution, the salt rejection is low, increases in PBS concentration result in lower of salt rejection.

Characterization and Performance Membrane CA/PBS in Various Solvent

The results of peak $-\mathrm{OH}$ analysis in the $\mathrm{CA} / \mathrm{PBS} /$ mixing solvent. Are of peak $-\mathrm{OH}$ read in Table 3 with the variation of solvent AcetoneNMP; Acetone-DMF; and Acetone-THF. Table 3 shows the result of the measurements of the $-\mathrm{OH}$ area; it is known that there are an increase and decrease in the area of a peak $-\mathrm{OH}$ group in the FTIR result. On CA/PBS membranes with a variety of solvent acetoneNMP, with the increasing of PBS polymer content, the area of $-\mathrm{OH}$ groups decrease. The use of solvent NMP can make finger-like membrane pores.

According to Hasen, the permanent dipole-dipole interactions $\left(\delta_{p}\right)$, dispersive $\left(\delta_{d}\right)$, and hydrogen bonding forces $\left(\delta_{h}\right)$ should be taken into consideration. Consequently, the solubility parameters $\delta$ can calculate as follows in Equation (4):

$\delta^{2}=\delta_{d}^{2}+\delta_{p}^{2}+\delta_{h}^{2}$

The Hansen solubility parameter differences among the solvent and the membrane forming polymers were computed using Equation (5).

$\Delta=\sqrt{\left[\left(\delta_{P, d}-\delta_{S, d}\right)^{2}+\left(\delta_{P, p}-\delta_{S, p}\right)^{2}+\left(\delta_{P, h}-\delta_{S, h}\right)^{2}\right]}$

Where $S$ and $P$ denote the solvent and polymer respectively and $p$, $d$, and $h$ represent for polar, dispersive, and hydrogen bonding elements of the Hansen solubility parameter. The polymer-solvent interaction parameter is inversely proportional with the Hansen solubility parameter $(\Delta)$, the smaller difference between the solubility 
parameters of polymer and solvent, the stronger the polymer-solvent interaction. The result of the solubility parameter difference is in Table 4. The composition of acetone-NMP solvents with 50:50 variation has smaller RHSP(s-p) values compared to just acetone can be seen at Table 4, which means that the interaction between the solvent and water will be fast or is called rapid de-mixing which results in the formation of finger-like pores. ${ }^{17}$

Table 3. Hydrophilicity and pore size of membranes in various solvent

\begin{tabular}{cccc}
\hline $\begin{array}{c}\text { Variable } \\
\text { Membrane }\end{array}$ & $\begin{array}{c}\text { Water Content } \\
(\%)\end{array}$ & $\begin{array}{c}\text { Area of } \\
\text {-OH Peak } \\
\text { (unit area) }\end{array}$ & $\begin{array}{c}\text { Pore Size } \\
(\mu \mathrm{m})\end{array}$ \\
\hline CPBAN1 & 73.45 & 6.15 & 0.15 \\
CPBAN2 & 76.98 & 7.05 & 0.18 \\
CPBAN3 & 14.20 & 5 & 1.19 \\
CPBAN4 & 74.51 & 5 & 0.041 \\
CPBAN5 & 77.05 & 4.5 & 0.204 \\
CPBAN6 & 74.76 & 2.88 & 0.2 \\
CPBAN7 & 79.75 & 2.85 & 0.1 \\
CPBAN8 & 76.32 & 3.17 & 0.2 \\
\hline CPBAD1 & 8.05 & 3.12 & - \\
CPBAD2 & 72.54 & 4.99 & 0.24 \\
CPBAD3 & 61.88 & 4.97 & 0.10 \\
CPBAD4 & 73.22 & 4.23 & 0.91 \\
CPBAD5 & 70.22 & 4.46 & 0.25 \\
CPBAD6 & 79.14 & 3.37 & 0.29 \\
\hline CPBAT1 & 22.68 & 5.2 & 0.4 \\
CPBAT2 & 11.61 & 5.59 & 0.2 \\
CPBAT3 & 14.20 & 2.64 & - \\
CPBAT4 & 65.35 & 4.9 & 0.2 \\
CPBAT5 & 68.80 & 2.65 & 0.306 \\
CPBAT6 & 75.52 & 3.20 & 0.2 \\
\hline
\end{tabular}

Cross-sectional images of the membrane with various compositions were depicted in Figure 3. Asymmetric structure all membranes comprise a dense top layer and a porous sublayer. As shown, pure CA with solvent acetone-NMP membrane has fully developed finger-like pores formed in the sublayer. However, mixing CA with PBS has gradually changed the final structure of the blend samples to spongy form. This variation is clearly obvious, which refers to delay de-mixing during the process of the membrane solidification in a coagulation bath, as mentioned by some researchers. ${ }^{16-18}$

Table 4. RHSP (S-P) and RHSP (S-W) of solvents with Hansen Solubility Equation

\begin{tabular}{lll}
\hline \multicolumn{1}{c}{ Ratio } & \multicolumn{1}{c}{$\operatorname{RHSP}_{(\mathrm{s}-\mathrm{P})}$} & \multicolumn{1}{c}{$\operatorname{RHSP}_{(\mathrm{s}-\mathrm{w})}$} \\
\hline Acetone (100) & 16.128 & 33.146 \\
Acetone:NMP (50:50) & 18.755 & 32.286 \\
Acetone:DMF (50:50) & 18.90 & 31.06 \\
Acetone:THF (50:50) & 6.81 & 36.56 \\
\hline
\end{tabular}

It can be seen in Figure 3 this group has finger-like pore in CPBAN1 until CPBAN4, but the addition of PBS can eliminate finger pores and make the membrane have sponge pores, and the best of CA/PBS with the acetone-NMP membrane is CPBAN5 with salt rejection as shown in Figure 4 is $71.43 \%$ and directly proportional to the permeate flux is $2500 \mathrm{~L} / \mathrm{m}^{2} \mathrm{~h}$.
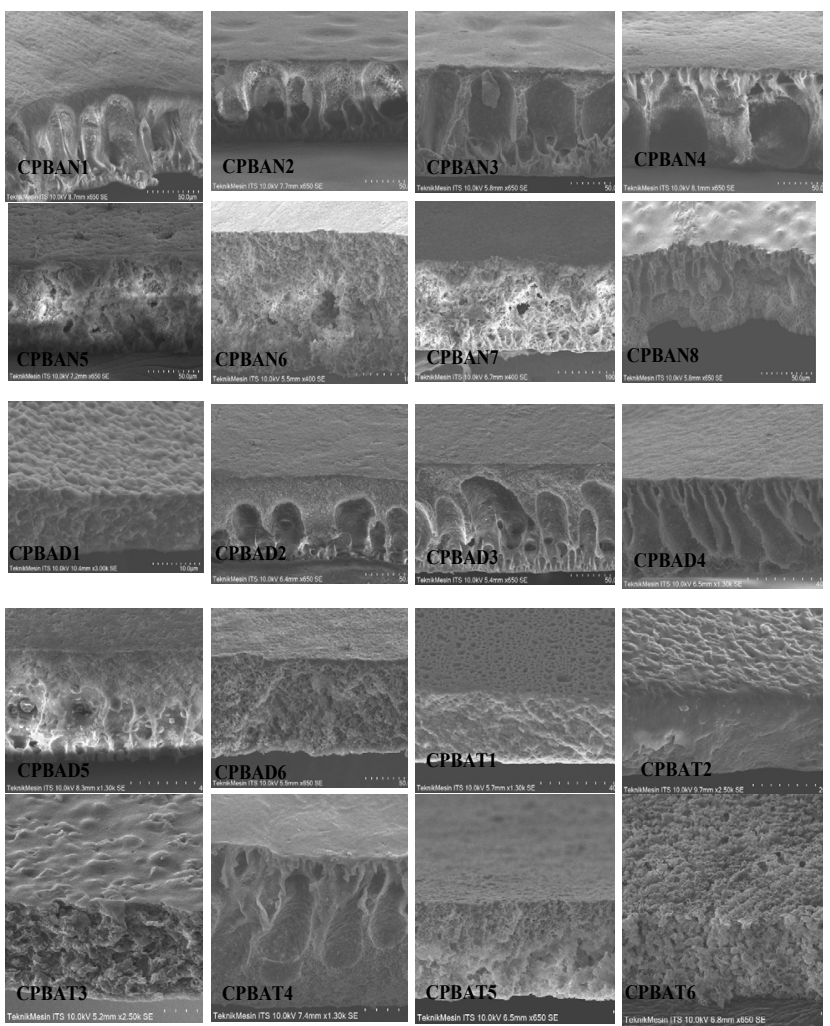

Figure 3. SEM Cross-sectional Image of the CA/PBS/variation solvent Membranes.

Table 3 also presents the area of $-\mathrm{OH}$ in CA/PBS membranes with a variety of solvent acetone-DMF. It can be seen that the addition of PBS can increase the $\mathrm{OH}$ group's area with the addition of $10 \%$ wt PBS. DMF solvent ratio up to $50 \%$ can increase the interval of finger-like pore width and sponge-like pore diameter. ${ }^{19}$ But the addition of PBS up to $50 \%$ can eliminate finger pores and make the membrane have sponge pores, which can be seen in Figure 3. This can be used in the Equation (4) the composition of acetone-DMF 50:50 has smaller RHSP(s-p) values compared to just acetone can be seen at Table 4, which means that the interaction between the solvent and air will be fast or is called rapid de-mixing which results in the formation of finger-like pores. The best of CA/PBS with the acetone-DMF membrane is CPBAD2 with salt rejection in Figure 4 is $66.67 \%$ with permeate flux is $2043.23 \mathrm{~L} / \mathrm{m}^{2} \mathrm{~h}$. The $-\mathrm{OH}$ area of CA/PBS membranes with a variety of solvent acetone-THF also summarized in Table 3. It can be seen that the addition of PBS can increase $\mathrm{OH}$ groups up to $5.59 \mathrm{~cm}^{2}$ at the addition of PBS $10 \% \mathrm{wt}$.

THF ratio up to $50 \% \mathrm{v}$ can eliminate the interval of finger-like pore width and increase sponge-like pore diameter because in the Equation (4) the composition of the acetone-THF 50:50 has greater than RHSP(s-p) values compared to just acetone can be seen on Table 4 , which means that the interaction between the solvent and air 
will be slow or is called delayed de-mixing which results in the formation of eliminate finger-like pores and increase sponge-like. The best of CA/PBS with acetone-THF membrane is CPBAT2 with salt rejection in Figure 3 is $23.337 \%$ with permeate flux is $928 \mathrm{~L} / \mathrm{m}^{2} \mathrm{~h}$.

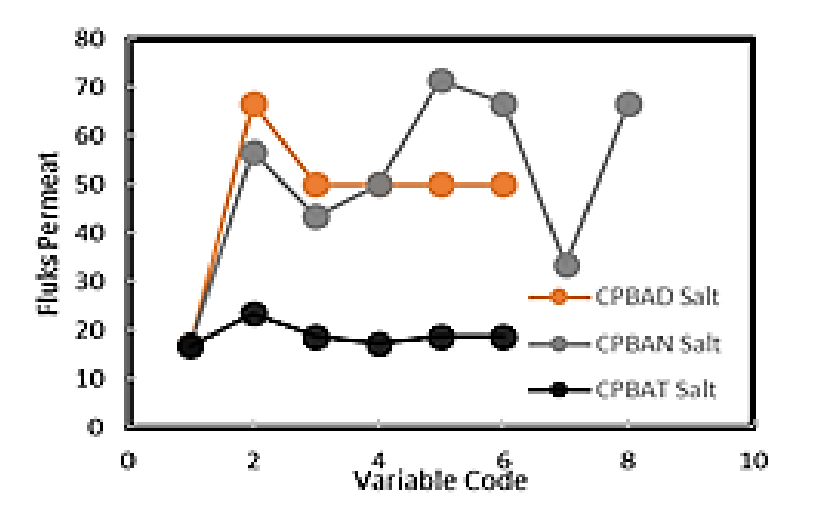

(a)

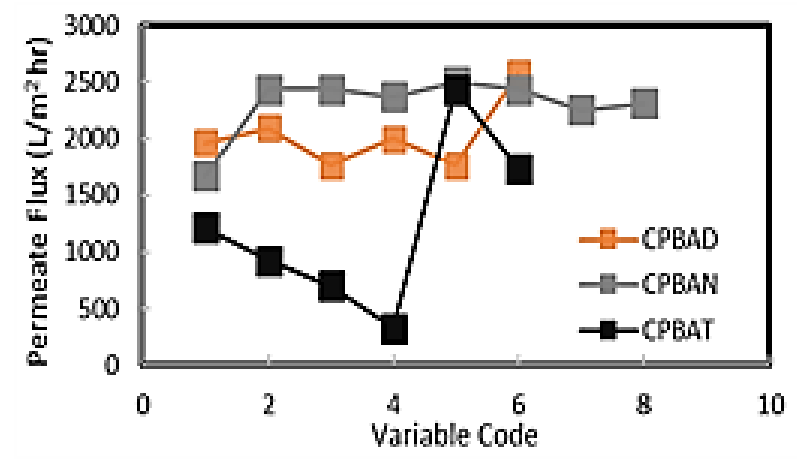

(b)

Figure 4. (a) Salt rejection and (b) permeate flux of CA/PBS/Mixing solvent membranes.

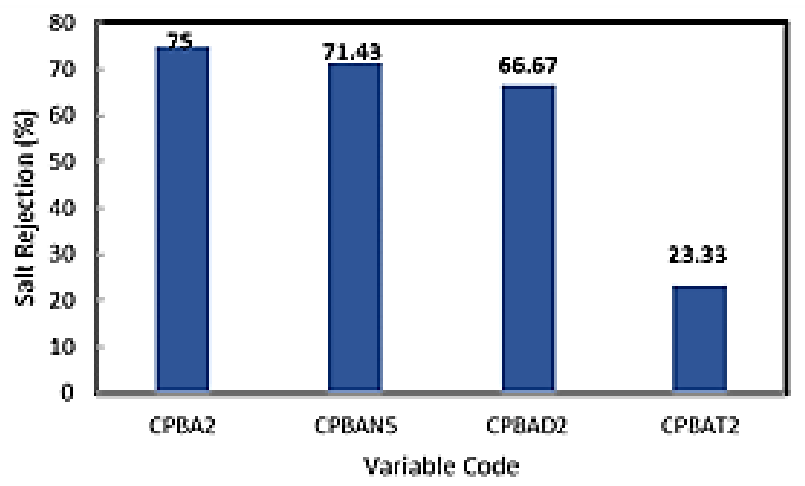

Figure 5. Salt rejection of the four best membranes.

\section{Comparison Best Result from Various Solvent Variations}

The four best membranes (CPBA2, CPBAN5, CPBAD2, and CPBAT2) among various studied using different solvents can be seen in Figure 5. This result is in agreement with pore size analysis from SEM images. The highest salt rejection is found in CPBA2 with has the smallest pore size due to the use of acetone as a solvent; this result is in accordance with research conducted by Derdoy. ${ }^{20}$ Variable CPBAT2 has the lowest performance results because THF has the smallest boiling point, which results in the results of membrane characteri- zation with an acetone-THF mixture having larger pores. From Figure 5 , it is concluded that the performance of CA/PBS membranes is affected by the solvent, and the order is acetone $>$ acetone/NMP > acetone/DMF > acetone/THF.

\section{Conclusions}

CA/PBS membranes were synthesized using the phase inversion method with the variation of mixing solvent. Destabilization of the casting solution by the addition of the PBS somewhat limits the growth of the polymer-lean phase and thus the growth of the macro voids, which consequently facilitates the formation of a sponge-like structure.

For all variables of solvents used, salt rejection of membranes increases with the addition of PBS. In terms of salt rejection, the order of solvents resulting in membrane with high salt rejection is acetone, acetone/NMP, acetone/DMF, and acetone/THF. Membrane with the highest performance is CA/PBS membrane prepared by using acetone as a solvent with a variation of CA/PBS is $90 / 10$ with the salt rejection of $75 \%$, permeate flux of $1956.52 \mathrm{~L} / \mathrm{m}^{2} \mathrm{~h}$, pore size $0.26 \mu \mathrm{m}$ and area of $-\mathrm{OH}$ peak is 4.8 unit are.

\section{Conflicts of Interest}

There are no conflicts to declare.

\section{Acknowledgments}

This work has been financially supported by the Ministry of Research, Technology, and Higher Education of the Republic of Indonesia with contract's number 7/E/KPT/2019 and $717 /$ PKS/ITS/2019 to which the authors express their sincerest gratitude.

\section{References}

1 P. Taylor, V. Ghaffarian, S. M. Mousavi, M. Bahreini, and H. Chamani, Poly (Butylene Succinate)/Polyethersulfone/Poly (Ethylene Glycol) Membrane : Influence of Additive Molecular Weight and Concentration on Morphology, Properties, and Performance of the Membrane, Des. and Water Treat., 2015, 57(36), 1-10.

2 A. Ali. H. Bahremand and S. Mahmoud, Acetate/Dextran Preparation, Characterization and Performance, Carbohydr. Polym., 2017, 173, 497-507.

3 M. Mulder, Basic Principle of Membrane Technology, London, 1996.

4 T. H. Young and L. W. Chen, Pore Formation Mechanism of Membranes from Phase Inversion Process, Desalination, 1995, 103, 233-247.

5 K. A. Gebru and C. Das, Effects of Solubility Parameter Differences among PEG, PVP and CA on the Preparation of Ultrafiltration Membranes: Impacts of Solvents and Additives on Morphology, Permeability and Fouling Performance, Chinese $J$. Chem. Eng., 2017, 25, 911-923. 
6 G. Arthanareeswaran, P. Thanikaivelan, K. Srinivasn, D. Mohan, and M. Rajendran, Synthesis, Characterization and Thermal Studies o Cellulose Acetate Membranes with Additive, Eur. Polym. J., 2004, 40, 2153-2159.

7 E. Saljoughi and T. Mohammadi, Cellulose Acetate (CA)/Polyvinylpyrrolidone (PVP) Blend Asymmetric Membranes: Preparation, Morphology and Performance, Desalination, 2009, 249, 850-854.

8 E. Saljoughi, M. Amirilargani, and T. Mohammadi, Effect of PEG Additive and Coagulation Bath Temperature on the Morphology, Permeability and Thermal/Chemical Stability of Asymmetric CA membranes, Desalination, 2010, 262, 72-78.

9 S.A. Hosseini S.M. Mousavi, E. Saljoughi, Z. Ghasemipour, Preparation and Characterization of Modified Polysulfone Membranes With High Hydrophilic Property Using Variation in Coagulation Bath Temperature and Addition of Surfactant, Polym. Eng. Sci., 2012, 47, 21-25.

10 J. H. Kim and K. H. Lee, Effect of PEG additive on membrane formation by phase inversion, J. Memb. Sci., 1998, 138, 153-163.

11 S. Lee and M. Kim, International Biodeterioration \& Biodegradation Isolation of Bacteria Degrading Poly (Butylene SuccinateCo-Butylene Adipate) and their Lip A Gene. Int. Biodeterior, Biodegradation, 2010, 64, 184-190.

12 C. Kanemura, S. Nakashima, and A. Hotta, Mechanical Properties and Chemical Structures of Biodegradable Poly (ButyleneSuccinate) for Material Reprocessing, Polym. Degrad. Stab., 2012, 97, 972-980.
13 A. Sabir et al., Fabrication of Tethered Carbon Nanotubes in Cellulose Acetate/Polyethylene Glycol-400 Composite Membranes for Reverse Osmosis, Carbohydr. Polym., 2015, 132, 89597.

14 E. Saljoughi, M. Sadrzadeh, and T. Mohammadi, Effect of Preparation Variables on Morphology and Pure Water Permeation Flux Through Asymmetric Cellulose Acetate Membranes, J. Memb. Sci., 2009, 326, 627-634.

15 E. Celik, H. Park, H. Choi, and H. Choi, Carbon Nanotube Blended Polyethersulfone Membranes for Fouling Control in Water Treatment, Water Res., 2011, 45, 274-282.

16 V. Ghaffarian, S. M. Mousavi, M. Bahreini, and M. Afifi, Preparation and Characterization of Biodegradable Blend Membranes of Pbs/Ca, J. Polym. Environ., 2012, 21, 1150-1157.

17 E. Bagheripour, A. R. Moghadassi, and S. M. Hosseini, Novel Nanofiltration Membrane with Low Concentration of Polyvinylchloride : Investigation of Solvents' Mixing Ratio Effect (Dimethyl Acetamide/Tetrahydrofuran), Arab. J. Chem., 2014.

18 D. I. Cha and K. W. Kim, G. H. Chu, H. Y. Kim, K. H. Lee, N. Bhattarai, Mechanical Behaviors and Characterization of Electrospun Polysulfone/Polyurethane Blend Nonwovens, Macromolecular Research, 2006, 14(3), 331-337.

19 E. Bagheripour, A. R. Moghadassi, and S. M. Hosseini, Novel Nanofiltration Membrane with Low Concentration of Polyvinylchloride: Investigation of Solvents' Mixing Ratio Effect (Dimethyl Acetamide/Tetrahydrofuran), Arab J. Chem., 2017, 10, S3375-S3380.

20 J. B. Derdory, Ensayo Del Uso Del Polisac'Arido De La Pseudomona Aeruginosa En Urolog'la, Rev. Argent. Urol. Nefrol, 1963, 32, 20-29. 